\title{
AGE-DEPENDENT RESPONSE OF MIGRANT AND RESIDENT AEGOLIUS OWL SPECIES TO SMALL RODENT POPULATION FLUCTUATIONS IN THE EASTERN CANADIAN BOREAL FOREST
}

\author{
MATHIEU CôTÉ ${ }^{1}$ \\ Département de Biologie, Chimie et Géographie, Université du Québec à Rimouski, 300 Allée des Ursulines, \\ Rimouski, Québec, G5L 3A1, Canada
}

Département des Sciences Fondamentales, Université du Québec à Chicoutimi, 555 boul. Université, Chicoutimi, Québec, G7H 2B1, Canada

Martin-Hugues St-Laurent and Jean Ferron

Département de Biologie, Chimie et Géographie, Université du Québec à Rimouski, 300 Allée des Ursulines, Rimouski, Québec, G5L 3A1, Canada

\author{
RÉJEAN GAGNON \\ Département des Sciences Fondamentales, Université du Québec à Chicoutimi, 555 boul. Université, Chicoutimi, \\ Québec, G7H 2B1, Canada
}

\begin{abstract}
We investigated the relationship between late summer abundance of small rodents and fall migrant abundance of two nocturnal avian predators, the Boreal Owl (Aegolius funereus) and the Northern Saw-whet Owl (A. acadicus), during their fall movement/migration. In the eastern Canadian boreal forest, Boreal Owls are considered resident (with irruptive movements to the south thought to occur during periods of low prey availability), and Northern Saw-whet Owls migratory. Data on late summer abundance of small rodents collected between 1995 and 2004 were used to develop an index of prey availability. Data on the number and age of irrupting/migrating owls were collected between 1996-2004 (mid-September to late October) using audiolures and mist nets. Our study revealed strong evidence of (1) a negative relationship between the abundance of small rodents and movement of Boreal Owls and (2) a positive relationship between the abundance of small rodents and the number of migrating juveniles and second year Northern Saw-whet Owls. In the latter case, it suggests that prey availability can strongly influence breeding success of this species, which is at the northern limit of its breeding range.
\end{abstract}

KeY WoRds: Boreal Owl; Northern Saw-whet Owl; Aegolius; boreal forest; fall migration; predator-prey relationships; small rodents.

RESPUESTA DEPENDIENTE DE LA EDAD DE BÚHOS MIGRATORIOS Y RESIDENTES DEL GÉNERO AEGOLIUS A FLUCTUACIONES POBLACIONALES DE ROEDORES PEQUEÑOS EN LOS BOSQUES BOREALES DEL ESTE DE CANADÁ

RESUMEN.-Investigamos la relación entre la abundancia de roedores pequeños hacia el final del verano y la abundancia de migrantes de dos especies de búhos depredadores nocturnos, Aegolius funereus y A. acadicus, durante sus movimientos de otoño. En los bosques boreales del este de Canadá, A. funereus se considera residente (con movimientos repentinos hacia el sur que se cree que tienen lugar en períodos de baja abundancia de presas), mientras que A. acadicus se considera una especie migratoria. Para desarrollar un índice de la disponibilidad de presas, se recolectaron datos de la abundancia de pequeños roedores hacia el final del verano entre 1995 y 2004. Se recolectaron datos sobre el número y la edad de búhos migrantes y migrantes repentinos utilizando señuelos de audio y redes de niebla. Nuestro estudio reveló evidencia

${ }_{1}^{1}$ Present address: Consortium en foresterie Gaspesie-Les-Iles, 37 rue Chrétien, bur. 26, c.p. 5, Gaspé, Québec, G4X 1E1, Canada. Email address: cote_mathieu@yahoo.com 
fuerte de la existencia de una relación negativa entre la abundancia de roedores pequeños y los movimientos de A. funereus y de una relación positiva entre la abundancia de roedores pequeños y el número de migrantes juveniles y de segundo año de A. acadicus. Esta última relación sugiere que la disponibilidad de presas puede influenciar fuertemente el éxito reproductivo de A. acadicus, que en el área de estudio alcanza el límite norte de su distribución geográfica.

[Traducción del equipo editorial]

Different owl species may be considered resident, migratory, or nomadic. Furthermore, in some species, there are individuals within the population in all three of these categories (Behrstock 2001). Some owl species are also known to undertake sporadic or periodic invasions or irruptions (Welty 1982), particularly in the arctic and subarctic regions (Gill 1989, Cheveau et al. 2004). These movements are frequently driven by resource availability, as there is evidence of the influence of food production on the choice between nomadism and site tenacity in many bird species (Andersson 1980). By modelling fitness associated with both strategies, Andersson (1980) demonstrated that the relative merit of nomadism is higher with cyclic than with random fluctuations in food abundance, and that it increases with the interval between successive good years of food production.

Two small owl species are found in the boreal black spruce (Picea mariana) forest of North America: the Boreal or Tengmalm's Owl (Aegolius funereus; hereafter referred to as Boreal Owl) and the Northern Saw-whet Owl (Aegolius acadicus; hereafter referred to as saw-whet owl). Although both feed predominantly on small rodents (Hayward et al. 1993, Holt and Leroux 1996), the Boreal Owl is considered to be resident, with periodic nomadic movements, and the saw-whet owl, whose range is parapatric and extends further south than the Boreal Owl, is considered as migratory in the northern part of its range (Cyr and Larivée 1995, David 1996).

In Canada, the Boreal Owl is considered to be widespread, the most common owl species in the boreal zone (Kirk 1995). However, most studies involving this circumboreal species have been conducted in Fennoscandia (Korpimäki 1981, 1986a, 1986b, 1992, Hörnfeldt and Eklund 1990, Hörnfeldt et al. 1990) and Central Rockies of North America (Hayward et al. 1993) where breeding success has been associated with food availability and, in particular, vole abundance (Korpimäki 1981, 1986b, 1992, Hörnfeldt and Eklund 1990). In Fennoscandia, this species is considered nomadic (exhibiting fall dispersal movement) during years of food scarcity (Saurola 1979, Korpimäki 1981, Löfgren et al.
1986, Hörnfeldt et al. 1990, Hakkarainen et al. 1997) or during years of heavy snowfall, where food accessibility was reduced (Korpimäki 1986a). This is a typical response for a resident avian species, which must constantly balance the potential lack of food during winter, which favours dispersal, and the lack of breeding sites, which enhances site fidelity (Lundberg 1979). Boreal Owls defend small breeding and winter territories (Hayward and Hayward 1993) but juveniles are not yet familiar with locations of suitable nest cavities, allowing them to potentially disperse in response to prey shortages without losing the benefits of site tenacity. In Fennoscandia, at the northern limit of their range where vole abundance fluctuations are of larger amplitude, fall movements of Boreal Owls (mainly females and juveniles) appear to be more pronounced than in the southern portion of their range (Korpimäki 1986a). In eastern Canada, very little is known about the precise distribution and population status of this species; however, it is considered to be resident, making irregular irruptions further south in severe winters (Catling 1972, Cheveau et al. 2004).

A close relative of the Boreal Owl, the saw-whet owl, is widespread in southern Canada and the northern United States. Although this species is usually considered to be present only in the southern part of the boreal forest (Gauthier and Aubry 1995), recent observations suggest that in Québec (Canada), it can nest north of $50^{\circ} \mathrm{N}$ latitude (Buidin and Rochepault 2002). Annual southern migrations have been well-documented at banding stations in the northeastern United States but the origin of these migrants is still largely undetermined (Brinker et al. 1997).

Small rodents, particularly voles, fluctuate synchronously over large areas in Fennoscandia and in northern North America (Krebs et al. 2002, Sundell et al. 2004), and exhibit regular multi-annual population fluctuations, with a periodicity ranging from 3-7 yr (Fryxell et al. 1998, Stenseth 1999, Klemola et al. 2002). In boreal regions, small rodents are major prey items for a wide range of predators, including marten (Martes americana), weasels (Mus- 
tela spp.) and Aegolius owls (Soutière 1979, Korpimäki 1981, Hanski et al. 1991, Hanski et al. 2001). Thus, large-scale fluctuations in their abundance have a major effect on higher trophic levels, particularly on small-mammal-specialists such as the Boreal Owl (Cheveau et al. 2004). In a recent study, Cheveau et al. (2004) concluded that southward irruptions of the Boreal Owl corresponded to years of low availability of its main prey species in the boreal forest, the red-backed vole (Clethrionomys gapperi). To our knowledge, no investigators have yet compared fall movements of two closely related owl species with different life strategies (i.e., resident or migratory) in relation to prey availability in the boreal forest.

The objective of this study was to analyze the degree of synchrony in populations of the resident Boreal Owl and the migratory saw-whet owl, in relation to fluctuations in the abundance of small rodents (their principal prey item) in the boreal black spruce forest of eastern North America. The relative abundance of adults and juveniles in the irrupting/ migrating population was used to interpret the influence of fluctuations in prey abundance on the reproductive success and on the population movements of these two owl species. We hypothesized that boreal and saw-whet owl abundance during fall movements is driven by late summer abundance of small rodents in the boreal zone. Furthermore, the movements of the migratory saw-whet owl will be positively related to small rodent abundance, while movements of the Boreal Owl will be negatively related to the same parameter. As the abundance of prey is expected to have a direct effect on breeding success, the abundance of juvenile saw-whet owl in the fall migrant population should be positively related to small rodent abundance. By contrast, in years when Boreal Owl dispersal occurs, fewer juveniles should be present due to poor breeding conditions caused by the scarcity of prey.

\section{MeTHODS}

Study Area. The study area was located in the central part of Québec's boreal forest zone (Fig. 1), within the breeding range of the Boreal Owl and at the northern limit of the distribution of the saw-whet owl (Gauthier and Aubry 1995). Because of the position of the St. Lawrence Estuary, Boreal Owls and saw-whet owls, which like many raptors are reluctant to cross a large body of water (Kerlinger 1989), move south from the study area, following the coastline during their autumn migration (Ibarzabal 1999). Many of these individuals pass through Tadoussac where they can be monitored at the Observatoire d'oiseaux de Tadoussac (OOT; Fig. 1) before they cross the St. Lawrence further west.

Small Rodent Abundance. An index of late summer (July-October) small rodent abundance was obtained from different datasets from studies conducted in mature stands in the boreal forest region of Québec $\left(49^{\circ} 00^{\prime}\right.$ to $50^{\circ} 45^{\prime} \mathrm{N}$, $68^{\circ} 30^{\prime}$ to $73^{\circ} 15^{\prime} \mathrm{W}$; Fig. 1). Data for 1999 were obtained from one night of snap-trapping in two grids (40 trapnights; M. Côté unpubl. data). Data for 2000, 2001, and 2002 were from a small rodent survey conducted in the same area for 3 consecutive nights in 15 grids [ 36 snaptraps per grid; 3240 trap-nights; see Côté et al. (2003) for further details]. Data for 2003 and 2004 were gathered during two consecutive nights in 100 grids in the same general area (0-100 km away) as the 2000-2002 study sites (9 snap-traps per grid; 3600 trap-nights; M.-H. St-Laurent unpubl. data). The number of small rodents caught was pooled (regardless of species) to calculate the prey abundance index. Traps that were closed but empty were compiled as half intervals of trapping (Nelson and Clark 1973). Additional data for red-backed voles from 1995-2001 (except for 1997 where no data exist in our study area) were obtained from the Québec small mammal Atlas (FAPAQ 2002). This Atlas combines data sets on small mammals from different studies conducted in the province of Québec. We extracted data sets from studies in mature spruce forests located close (100-500 km away) to our own trapping grids and pooled them as one index. All data were expressed as the number of catches per 100 trap-nights to establish a catch-per-unit-of-effort index (small rodent CPUE). For our analyses, we used the greatest abundance recorded (of either our data or FAPAQ's data) when data from more than one comparable study were available for a particular year.

Owl Abundance. Fall movements of Boreal and Northern Saw-whet Owls have been monitored at the OOT $\left(48^{\circ} 09^{\prime} \mathrm{N}, 69^{\circ} 42^{\prime} \mathrm{W}\right.$; Fig. 1) since 1996. Boreal and saw-whet owls were caught principally by using four mist nets $(9 \mathrm{~m} \times 2.3 \mathrm{~m}$; mesh $60 \mathrm{~mm})$ erected to form a square (enclosure) surrounding a continuously playing audiolure of calling male Boreal or saw-whet owls. This method is effective for capturing both owl species (Hayward et al. 1993, Erdman and Brinker 1997). Nets were opened $0.5 \mathrm{hr}$ after sunset for $7 \mathrm{hr}$ every night (except during rain events) between mid-September and the end of October (1996-2004). A single enclosure was used in 1996 and tapes of the two species were alternated; from 1997 to 2004, two enclosures were used. In addition to active mist netting, passive mist netting (without playing audiolure in it) was also used to increase the capture of attracted birds in all years except 2002. Passive netting comprised between one and seven additional mist nets hung in strategic corridors close (from 20-40 m) to the above-mentioned enclosures. The wing molt patterns of each owl caught was noted and used to determine bird age (Pyle 1997). Because trapping effort varied from year to year, the owl abundance index is expressed in terms of numbers of individuals per $1000 \mathrm{~m}$ of mist net per hour (owl CPUE). Such standardization may not control for all the variation in trapping effort, but we consider that this bias could not account alone for the large differences observed in owl abundance across years. 


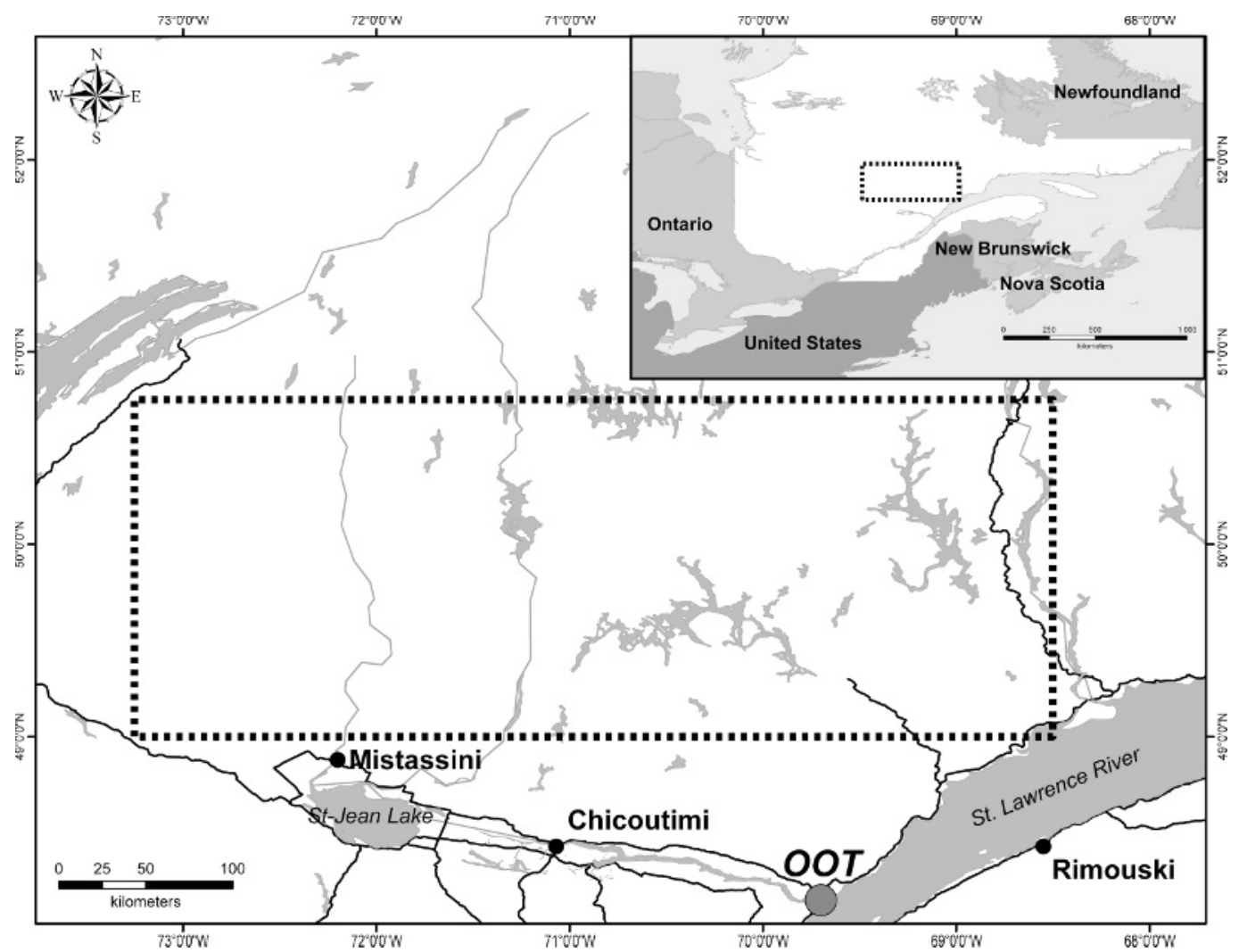

Figure 1. Map of northeastern North America showing the origin of the small rodent data sets and the location of the owl banding station (Observatoire d'oiseaux de Tadoussac; OOT). On the main map, major water bodies and rivers are in gray; national roads are in black.

Data Analyses. Transformation and standardization were considered but as multi-normality was not met, a Pearson correlation on ranked data was used to obtain a Spearman ranked-correlation to link predator and prey abundances (Legendre and Legendre 1998). Correlations between small rodent and owl CPUEs were done. For both owl species, we analysed data for juveniles, second-year birds, adults, and finally all age classes pooled. We also did power analyses to obtain the statistical power for a 0.05 alpha threshold. Such information supported the interpretation that can be made from $P$-values and helped in understanding the strength of relationships between variables. Similar analyses were conducted using time lags of -1 year and +1 year to verify whether stronger relationships could be obtained, and thus indicate a delay in predator responses to fluctuations in prey abundances. All statistical analyses were carried out using SYSTAT 11.0 (SYSTAT Software Inc., Richmond, CA, 2004).

\section{REsults}

Small Rodent and Owl Abundances. Low numbers of small rodents were recorded in 1996, 2000, 2001, and 2002. By contrast, relatively high numbers were recorded in 1998, 1999, 2003, and 2004 (Fig. 2, 3). The red-backed vole was the most common species caught (over $95 \%$ of small rodents captured). In 1996, 2000, and 2004, Boreal Owl numbers during fall were high for second year individuals, adults, and all age classes pooled. By contrast, few or no Boreal Owls were caught in 1998, 1999, 2002, and 2003 (Fig. 2), and 1997 and 2001 were intermediate years. The number of juveniles peaked in 2001 (although the difference with 2000 was marginal); all other age groups peaked in 2000. Saw-whet owls were captured every year between 1996 and 2004, but there was an interannual variation in the capture index. From 1997-1999, there were high numbers of juveniles, but the number of adults declined from 1996 to 1997 and remained at a low level thereafter (Fig. 3).

Predator-Prey Relationships. Small rodent CPUEs were negatively related to Boreal Owl CPUEs for most age classes (Spearman $r$ ranging from 


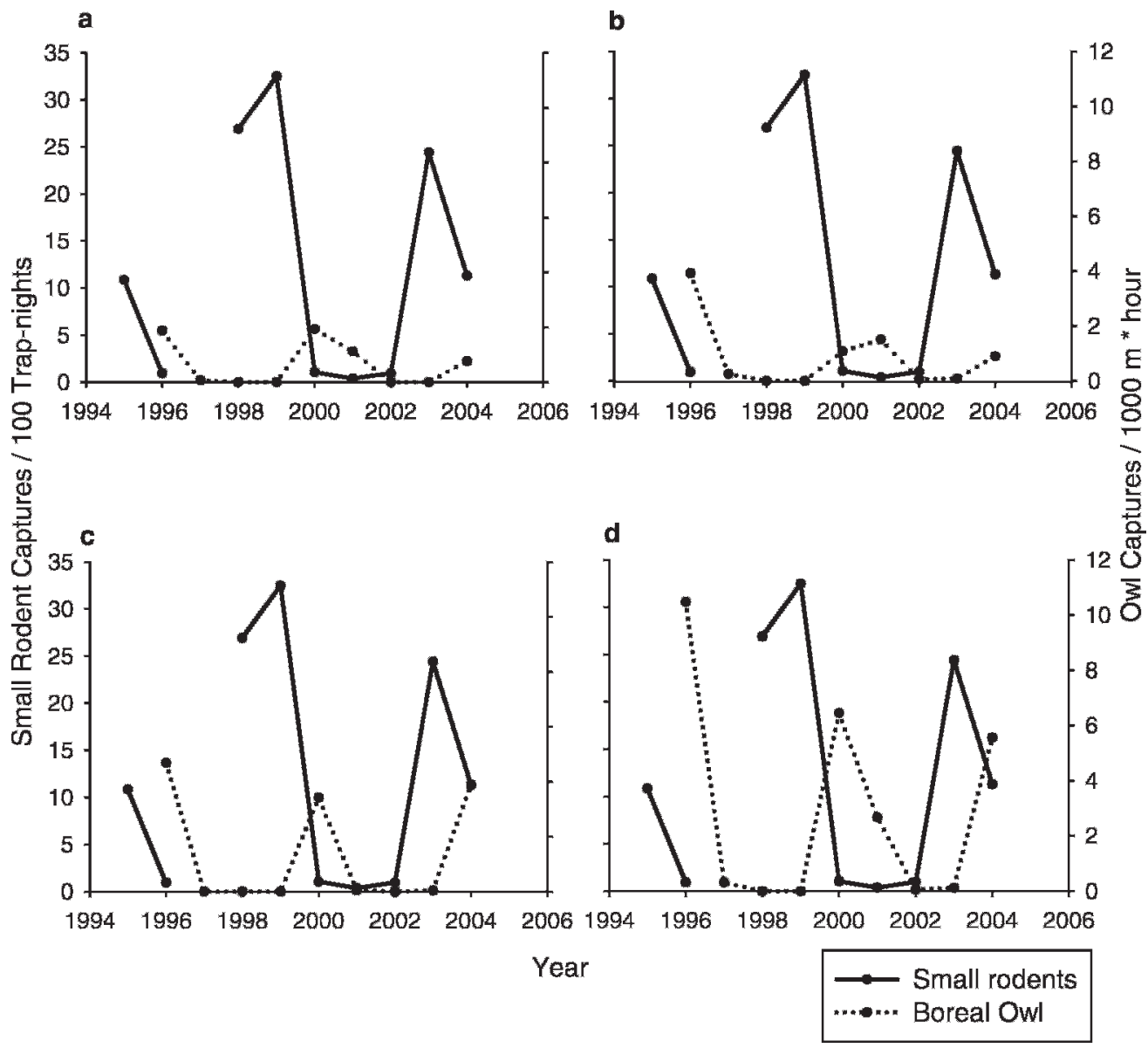

Figure 2. Graphs showing the relationship between Boreal Owl (Aegolius funereus) numbers and late summer abundance of small rodents in the eastern Canadian boreal forest for (a) adults, (b) juveniles, (c) second-year individuals and (d) all age classes pooled for the period 1996 to 2004.

-0.439 to -0.779 ; Table 1$)$. There was evidence for a relationship between rodent abundance and both juveniles and adults. Pooled results also suggest a strong relationship $(P=0.059)$. These three relationships had the highest statistical powers (ranging from 0.477 to 0.724 ). Only for second year Boreal Owls was there little evidence for a correlation with rodent abundance $(P=0.239$; Table 1$)$.

Weaker positive relationships (Spearman $r$ ranging between 0.014 and 0.669 ) were observed between small rodent and Northern Saw-whet Owl CPUEs (Table 1). The numbers of small rodents and second year owls were statistically significantly correlated, and there was a suggestion of a relationship for juveniles $(P<0.10$; Table 1$)$. For the adult saw-whet owls and the pooled age classes, no correlation was observed between small rodent and saw- whet owl abundance (Table 1). For both owl species, stronger correlations were obtained when no time delay was used; results for time delay are not shown.

\section{DISCUSSION}

In our study, the number of resident Boreal Owls caught during fall movements (dispersal movements) was negatively related to late summer small rodent abundance, while the abundance of the latter was positively related to the number of migrating saw-whet owls caught. Although the strength of the relationships observed varied depending on ageclass and species considered, we found evidence of correlation between owl and small rodent abundance in five out of eight cases. Thus, these results demonstrate how two closely-related small owl spe- 
a

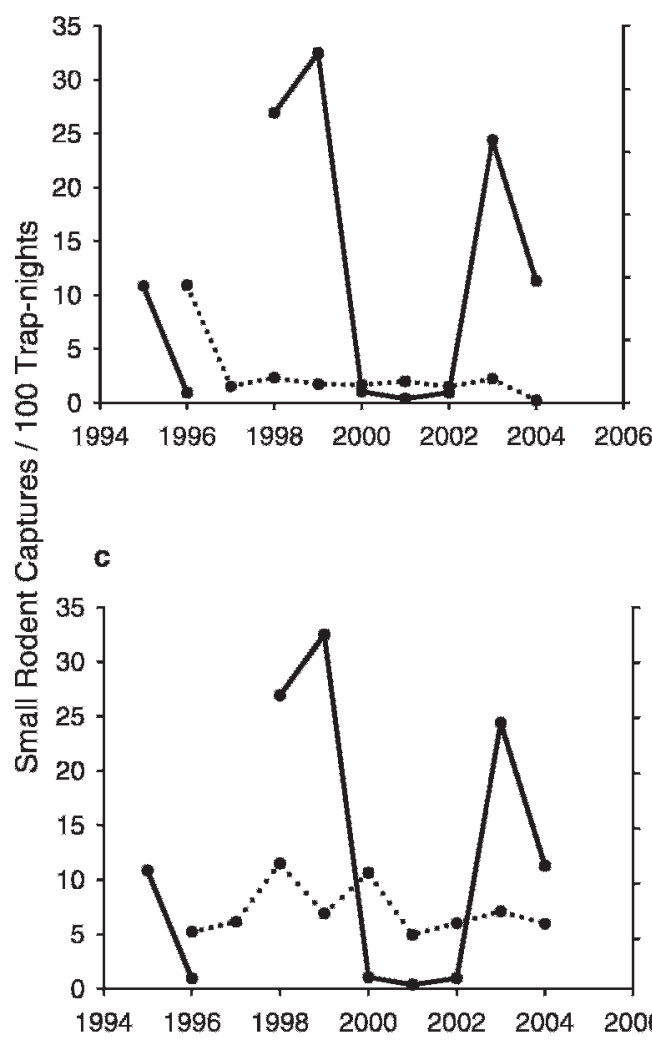

b

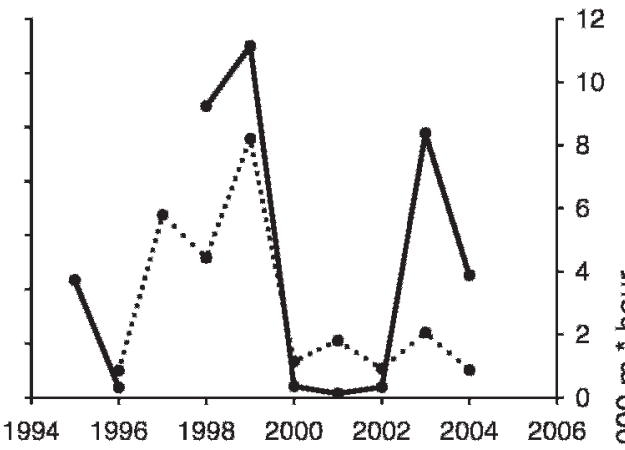

d
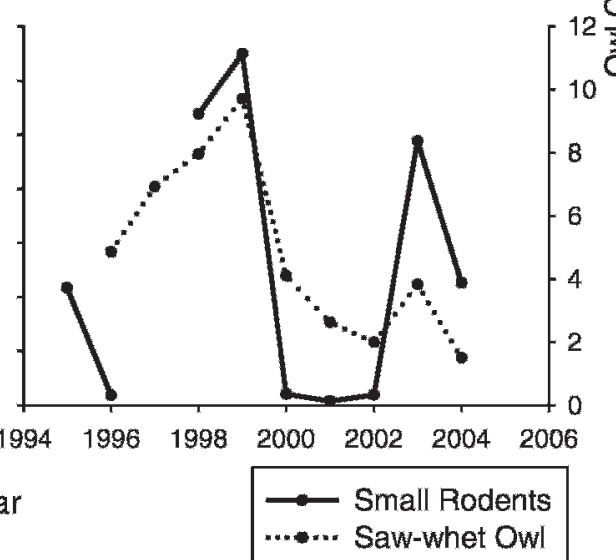

Figure 3. Graphs showing the relationship between saw-whet owl (Aegolius acadicus) numbers and late summer abundance of small rodents in the eastern Canadian boreal forest for (a) adults, (b) juveniles, (c) second year individuals and (d) all age classes pooled, for the period 1996 to 2004.

cies with different life strategies (i.e., resident or migratory) react differently to fluctuations in the small rodent population in a given area.

Boreal Owl fall movements were more intense in years of low small rodent abundance, whereas no owls were captured in years when rodent abundance was high. These results supported the conventional belief that this species is generally resident, but becomes nomadic when prey species are less numerous (Korpimäki 1986a, Cheveau et al. 2004). Similarly, Korpimäki (1993), showed that fewer Boreal Owls dispersed during the increasing than during the decreasing phase of the vole population cycle. These results strongly suggest that this resident cavity-nesting species in the boreal coniferous forest, where nesting cavities are rare (Hayward and Hay- ward 1993) due to low densities of Pileated Woodpeckers (Dryocopus pileatus) and Northern Flickers (Colaptes auratus; Gauthier and Aubry 1995), tends to remain in a known territory, becoming nomadic only when food is scarce. The age structure among migrants was also linked to rodent abundance, illustrating the influence of prey availability on breeding success and/or juvenile and adult dispersal (Sundell et al. 2004). Thus, individuals seemed less likely to disperse when they were able to find suitable foodrich territories in the boreal forest.

While no Boreal Owls were caught in 1998, 1999, 2002, and 2003, Northern Saw-whet Owls were caught every fall between 1996 and 2004. However, the results of our study, and those of Weir et al. (1980) and Cannings (1993), suggest that interan- 
Table 1. Spearman ranked-correlations between small rodent and owl abundances, in relation to owl species and age.

\begin{tabular}{llccccc}
\hline Owl Species & Age Class & SPearman $r$ & Bartlett $\chi^{2}$ & df & $P$ & Power \\
\hline Boreal Owl & Adult & -0.654 & 3.632 & 1 & 0.057 & 0.483 \\
(Aegolius funereus) & Juveniles & -0.779 & 6.073 & 1 & 0.014 & 0.724 \\
& Second year & -0.439 & 1.389 & 1 & 0.239 & 0.210 \\
& Pooled & -0.651 & 3.576 & 1 & 0.059 & 0.477 \\
Northern Saw-whet & Adult & 0.014 & 0.001 & 1 & 0.971 & 0.027 \\
Owl (A. acadius) & Juveniles & 0.598 & 2.876 & 1 & 0.090 & 0.394 \\
& Second year & 0.669 & 3.860 & 1 & 0.049 & 0.509 \\
& Pooled & 0.456 & 1.512 & 1 & 0.219 & 0.225 \\
\hline
\end{tabular}

nual fluctuations in the number of migrating individuals may be due almost entirely to differences in the number of Northern Saw-whet Owls hatching and fledging in a given year. Furthermore, the present results suggest that one of the principal causes of these fluctuations was small rodent abundance. In contrast to Boreal Owls, more saw-whet owls migrated when rodent abundance was high, while fewer individuals were recorded when prey abundance was lower. This result was evident for second year birds and probably juveniles as well.

However, the number of migrating individuals does not depend entirely on the number of individuals hatching in a given year, but also on their survival. The positive correlation between second year Northern Saw-whet Owls and small rodent numbers suggested that juvenile saw-whet owls that survive in high numbers (because of high prey availability) return to breed in the same area and therefore account for large numbers of migrating second year individuals the following fall. This species is known to nest in the year after its hatch year (Cannings 1993) and, like the Boreal Owl, is more likely to nest in years when small rodent populations are high (Hayward and Hayward 1993). That the number of adult saw-whet owls caught remained fairly constant suggested that individuals in this part of the population (at the northern limit of the breeding range) undertake an annual migration.

There are very few reported cases of saw-whet owls breeding north of $50^{\circ} \mathrm{N}$ in Québec (but see Buidin and Rochepault 2002). It is possible that the sawwhet owls in the boreal coniferous forest caught at the OOT might not be northern breeders migrating southward, but might be birds that had undertaken postnuptial (for adults) or juvenile dispersal movements. This hypothesis was supported by the case of an adult female saw-whet owl that was banded while it was incubating $350 \mathrm{~km}$ southwest of Tadoussac, and caught later the same year at the OOT. Moreover, juveniles and second year birds without territories could be exploring the limit of the species' range for food availability. If this were the case, the breeding success of the saw-whet owl would not be linked to small rodent population levels in the boreal forest. However, given the number and regularity of occurrence of this species at the OOT, it is unlikely that this interpretation of the results is correct for this part of the boreal forest. Nevertheless, it would be interesting to address this possibility through study of nest box use, coupled with fall monitoring, and the use of stable isotope signatures in feathers, which would allow the comparison of fall latitude with hatching or breeding latitude.

Our data confirmed that in the boreal forest of eastern North America, fall movements of these two owl species show fluctuations in number that are strongly associated with small rodent population levels. Furthermore, our study supports the findings of Korpimäki (1994) that the density of avian predators shows the same trends as prey abundance, and with no obvious time lag.

At least for Boreal Owls, prey selection depends on species availability (Korpimäki 1981). This species preys predominantly on voles during peak years; however, it may rely on shrews (Sorex sp.), other small mammals, and even birds during periods of low vole abundance (Korpimäki 1981, Hayward et al. 1993). Although the analysis of shrew numbers was not included in this study, data from the study area for July 2001 (M. Côté unpubl. data) showed relatively high shrew abundance (up to 17 individuals per 100 trap-nights) while other small mammal numbers were still relatively low $(<1$ catch per 100 trap-nights). Shrew availability could therefore explain the constant incidence of migrant sawwhet owls in the boreal forest even when the overall abundance of rodents was still relatively low, assum- 
ing that saw-whet owls would also switch to other prey as do Boreal Owls.

In our study, population levels of small rodents were evaluated at the end of the summer, at a time when both owl species had completed their reproduction. Thus, the measured population level of small rodents was more closely associated with the period of fledging and juvenile independence, rather than the time of clutch formation or the nestling period. It is possible that during spring, owls have moderate breeding success due to low levels of small rodent population, but those rodent populations could have partly recovered by the time that late summer fieldwork was conducted. A better way to test the relationship between rodent populations and owl breeding success and survival until fall dispersal may be to obtain population levels of small rodents and shrews from April-May and again at the end of the summer.

To conclude, our investigation was the first to determine the influence of small rodent abundance on the different age groups of Boreal and Northern Saw-whet Owls during fall movement/migration in eastern North America. Our study underscored the fact that Boreal Owls undertake irruptive movements south when small rodents are low in abundance, whereas saw-whet owls appear to be regular migrants in the southern part of the boreal forest. Furthermore, in the eastern North American boreal forest, the amplitudes of the movement/migration of these two owl species are related to the abundance of small rodents, particularly for the juvenile portion of the population. Continued banding of Aegolius owl species at northern bird observatories, such as the OOT, will provide important information concerning the numbers of migrating Boreal and Northern Saw-whet Owls and could, indirectly, provide information about rodent population levels in the boreal forest of eastern North America.

\section{ACKNOWLEDGMENTS}

We would like to thank Y. Rochepault, N. Duchesne, and M. Savard for conducting fieldwork on owl migration and M.-C. Rancourt, M. Perreault, É. Berthiaume, M.-É. Banville, S. Haché, C. Hins, F. Boulianne, S. Boudreault, and M. Bouliane for sampling small rodents. We also wish to thank R. Morin from La Société de la Faune et des Parcs du Québec (FAPAQ) for providing data on small rodents from the Atlas des micromammifères du Québec, G. Lupien (FAPAQ) for the identification of captured small rodents, and J.-F. Ouellet and A.P. Coughlan for reviewing an earlier version of this manuscript. We wish to thank the Observatoire d'oiseaux de Tadoussac, Corporation ExplosNature for providing access to their owl database. We are grateful to the Consortium de recherche sur la forêt boréale commerciale and the FQRNT for logistic and financial support. We also want to thank Marni Koopman and Janne Sundell for their constructive comments on this paper. Finally we thank NSERC and the FQRNT for scholarships to M. Côté, and the FQRNT, the Fondation de l'Université du Québec à Montréal, the Consortium de recherche sur la forêt boréale commerciale and the Université du Québec à Rimouski for scholarships to M.-H. StLaurent.

\section{Literature Cited}

ANDERsSon, M. 1980. Nomadism and site tenacity as alternative reproductive tactics in birds. J. Anim. Ecol. 49:175-184.

Behrstock, R.A. 2001. Typical Owls. Pages 339-347 in C. Elphick, J.B. Dunning, Jr., and D.A. Sibley [EDs.], The Sibley guide to bird life and behavior. Chanticleer Press, New York, NY U.S.A.

Brinker, D.F., K.E. Duffy, D.M. Whalen, B.D. Watts, And K.M. Dodge. 1997. Autumn migration of Northern Saw-whet Owls (Aegolius acadicus) in the middle Atlantic and northeastern United States: what observations from 1995 suggest. Pages 74-89 in J.R. Duncan, D.H. Johnson, and T.N. Nicholls [EDS.], Biology and conservation of owls of the northern hemisphere: $2^{\text {nd }}$ international symposium. USDA Forest Service, General Technical report NC-190, North Central Forest Experiment Station, St. Paul, MN U.S.A.

Buidin, C. And Y. Rochepault. 2002. Petite nyctale en Minganie: la nidification inattendue. Québec Oiseaux 13: 40-42.

CAnnings, R.J. 1993. Northern Saw-whet Owl (Aegolius acadicus). In A. Poole and F. Gill [EDs.], The birds of North America, No. 42. The Academy of Natural Sciences, Philadelphia, PA and The American Ornithologists' Union, Washington, DC U.S.A.

Catling, P.M. 1972. A study of the Boreal Owl in southern Ontario with particular reference to the irruption of 1968-69. Can. Field-Nat. 86:223-232.

Cheveau, M., P. Drapeau, L. Imbeau, and Y. Bergeron. 2004. Owl winter irruptions as an indicator of small mammal population cycles in the boreal forest of eastern North America. Oikos 107:190-198.

Côté, M., J. Ferron, ANd R. GaGnON. 2003. Impact of seed and seedling predation by small rodents on early regeneration establishment of black spruce. Can. J. For. Res. 33:2362-2371.

Cyr, A. and J. Larivée. 1995. Atlas Saisonnier des Oiseaux du Québec. Les Presses de l'Université de Sherbrooke et Société du loisir ornithologique de l'Estrie, Sherbrooke, Québec, Canada.

David, N. 1996. Liste Commentée des Oiseaux du Québec. Association Québécoise des Groupes d'Ornithologues, Montréal, Québec, Canada.

ERdMAN, T.C. AND D. BRINKER. 1997. Increasing mist net captures of migrant Northern Saw-whet Owls (Aegolius acadicus) with an audiolure. Pages 533-544 in J.R. Dun- 
can, D.H. Johnson, and T.N. Nicholls [EDs.], Biology and conservation of owls of the northern hemisphere: 2nd international symposium. USDA Forest Service, General Technical report NC-190, North Central Forest Experiment Station, St. Paul, MN U.S.A.

FAPAQ. 2002. Atlas des Micromammifères du Québec: base de données [fichier d'ordinateur]. Version 2.1., Société de la faune et des parcs du Québec Direction du développement de la faune, 2000. Base de données réalisée avec le logiciel Microsoft Access 97, Québec, Québec, Canada.

Fryxell, J.M., J.B. Falls, E.A. Falls, and R.J. Brooks. 1998. Long term dynamics of small-mammal populations in Ontario. Ecology 79:213-235.

Gauthier, J. ANd Y. Aubry. 1995. Les Oiseaux Nicheurs du Québec: Atlas des Oiseaux Nicheurs du Québec Méridional. Association québécoise des groupes d'ornithologues, Société québécoise de protection des oiseaux, Service canadien de la faune, Environnement Canada, région du Québec, Québec, Canada.

Gill, F.B. 1989. Ornithology. Freeman Press, New York, NY U.S.A.

Hakkarainen, H., V. Koivunen, And E. KorpimäKi. 1997. Reproductive success and parental effort of Tengmalm's Owls: effects of spatial and temporal variation in habitat quality. Ecoscience 4:35-42.

Hanski, I., L. Hansson, And H. HentTonen. 1991. Specialist predators, generalist predators, and the microtine rodent cycle. J. Anim. Ecol. 60:353-367.

- H. HentTonen, E. Korpimäki, L. OKsanen, And P. Turchin. 2001. Small-rodent dynamics and predation. Ecology 82:1505-1520.

Hayward, G.D. and P.H. Hayward. 1993. Boreal Owl (Aegolius funereus). In A. Poole and F. Gill [EDs.], The birds of North America, No. 63. The Academy of Natural Sciences, Philadelphia, PA and The American Ornithologists' Union, Washington, DC U.S.A.

$\longrightarrow$, AND E.O. Garton. 1993. Ecology of the Boreal Owls in the northern Rocky Mountains, U.S.A. Wildl. Monogr. 124:1-59.

Holt, D.W. ANd L.A. Leroux. 1996. Diets of Northern Pygmy-Owls and Northern Saw-whet Owls in west-central Montana. Wilson Bull. 108:123-128.

HÖRNFELDT, B. AND U. EKLUND. 1990. The effect of food on laying date and clutch-size in Tengmalm's Owl Aegolius funereus. Ibis 132:395-406.

Hörnfledt, B., B.-G. Carlsson, O. Löfgren, and U. EkLUND. 1990. Effects of cyclic food supply on breeding performance in Tengmalm's Owl (Aegolius funereus). Can. J. Zool. 68:522-530.

IBARZABAL, J. 1999. Tadoussac: un site de migration des oiseaux de proie. Nat. Can. 123:11-18.

KerLinger, P. 1989. Flight strategies of migrating hawks. Univ. of Chicago Press, Chicago, IL U.S.A.

KIRK, D.A. 1995. Status report of the Boreal Owl Aegolius funereus in Canada. Committee on the status of endangered wildlife in Canada, Ottawa, Canada.
Klemola, T., M. TANHUANPÄA, E. KoRPIMÄKI, AND K. RuOHOMÄKI. 2002. Specialist and generalist natural enemies as an explanation for geographical gradients in population cycles of northern herbivores. Oikos 99: 83-94.

KORPIMÄKI, E. 1981. On the ecology and biology of Tengmalm's Owl (Aegolius funereus) in southern Ostrobothnia and Suomenselkä, Western Finland. Acta Universalis Ouluensis, Serie A Scientia rerum naturalium 118:1-84.

- 1986a. Gradients in population fluctuations of Tengmalm's Owl Aegolius funereus in Europe. Oecologia 69:195-201.

. 1986b. Timing of breeding of Tengmalm's Owl Aegolius funereus in relation to vole dynamics in western Finland. Ibis 129:58-68.

1992. Fluctuating food abundance determines the lifetime reproductive success of male Tengmalm's Owls. J. Anim. Ecol. 61:103-111.

1993. Does nest-hole quality, poor breeding success or food depletion drive the breeding dispersal of Tengmalm's Owls? J. Anim. Ecol. 62:606-613.

. 1994. Rapid or delayed tracking of multi-annual vole cycles by avian predators? J. Anim. Ecol. 63:619628.

Krebs, C.J., A.J. Kenney, S. Gilbert, K. Danell, A. AngerBJörn, S. ERlinge, R.G. Bromley, C. Shank, And S. CarRIERE. 2002. Synchrony in lemming and vole populations in the Canadian Arctic. Can.J. Zool. 80:1323-1333.

Legendre, P. AND L. Legendre. 1998. Numerical ecology, 2nd English Ed. Elsevier Science, Amsterdam, Netherlands.

LÖFgren, O., B. Hörnfeldt, AND B.-G. Carlsson. 1986. Site tenacity and nomadism in Tengmalm's Owl (Aegolius funereus (L.)) in relation to cyclic food production. $O e$ cologia 69:321-326.

LUNDBERG, A. 1979. Residency, migration and a compromise: adaptations to nest-site scarcity and food specialization in three Fennoscandian owl species. Oecologia 41:273-281.

Nelson, L., JR. AND F.W. Clark. 1973. Correction for sprung traps in catch/effort calculations of trapping results. J. Mammal. 54:295-298.

Pyle, P. 1997. Identification guide to North American birds. Part 1. Columbidae to Ploceidae. Slate Creel Press, Bolinas, CA U.S.A.

SAurola, P. 1979. Fall movements of Tengmalm's Owl in Finland. Lintumies 14:104-110.

Soutière, E.C. 1979. Effects of timber harvesting on marten in Maine. J. Wildl. Manage. 43:850-860.

Stenseth, N.C. 1999. Population cycles in voles and lemmings: density dependence and phase dependence in a stochastic world. Oikos 87:427-461.

Sundell, J., O. Huitu, H. Henttonen, A. Kaikusalo, E. Korpimäki, H. Pietiäinen, P. SAURola, ANd I. Hanski. 2004. Large-scale spatial dynamics of vole populations in Finland revealed by the breeding success of voleeating avian predators. J. Anim. Ecol. 73:167-178. 
SYSTAT SOFTWARE INC. 2004. SYSTAT 11.0 Statistical software. Point Richmond, CA U.S.A.

Weir, R.D., F. CoOke, M.H. Edwards, and R.B. STewart. 1980. Fall migration of saw-whet owls at Prince Edward Point, Ontario. Wilson Bull. 92:475-488.
Welty, J.C. 1982. The life of birds, 3rd Ed. Saunders Press, Philadelphia, PA U.S.A.

Received 20 June 2006; accepted 6 January 2007 Associate Editor: Ian G. Warkentin 